\title{
TO BRING ABOUT A CHANGE IN KNOWLEDGE, ATTITUDE AND PRACTICE REGARDING GUTKHA CHEWING AMONG STUDENTS OF ST. MARY'S H. S. SCHOOL, INDORE
}

\author{
Sonu Shukla1 \\ ${ }^{1}$ Assistant Professor, Department of Dentistry, L. N. Medical College, J. K. Hospital, Bhopal.
}

\section{ABSTRACT}

\section{BACKGROUND}

Consumption of tobacco is one of the greatest threat to global health today. It is estimated that in the middle or low income group countries, there are 1.2 billion tobacco users alive. It has been reported that a considerable number of tobacco chewers develop this habit during adolescence and hence this study was performed.

\section{AIM}

1. To study the knowledge, attitude and practice regarding gutkha chewing in school children. 2 . To study prevalence of gutkha chewing in school children in terms of frequency, type expenditure, cause, duration and age of starting.

\section{METHOD USED}

50 students of St. Mary's H.S. School were involved and were given a pre-intervention questionnaire. Lectures were taken to explain hazards of tobacco and after a month's time students were given a post-intervention questionnaire. The data collected by the questionnaire was tabulated and simple mathematical calculations were used to obtain results.

\section{RESULTS}

An improvement of $21 \%$ was seen in the number of students indulging in gutkha chewing from pre-intervention to postintervention.

\section{KEYWORDS}

Gutkha, Tobacco, Pre-Malignancy, Habit.

HOW TO CITE THIS ARTICLE: Shukla S. To bring about a change in knowledge, attitude and practice regarding gutkha chewing among students of St. Mary's H.S. School, Indore. J. Evolution Med. Dent. Sci. 2016;5(51):3239-3241, DOI: $10.14260 /$ jemds/2016/751

\section{INTRODUCTION}

Each year tobacco kills 3 million people worldwide. WHO has estimated that by 2020-2030, tobacco will be responsible for 10 million deaths per year, of which $70 \%$ occurring in developing countries. In the developing world, tobacco poses a major challenge not just to health, but also to social and economic development and environmental sustainability. According to study by World Bank (1994), tobacco results in a global net loss of USD 2,00,000 million per years with half of this in developing countries. These costs include (a) Direct medical care for tobacco related illness, (b) Absenteeism from work, (c) Reduced productivity, (d) Forgone income due to early mortality. In the Indian sub-continent, the use of betel nut in various forms is very popular. This is prevalent either in the form of brand nuts or in the form of 'Gutkha,' a preparation of tobacco, betel nut, areca, lime and flavouring agents. ${ }^{1,2,3}$

This condition SMF is found in 4 per thousand adults in rural India. The disease as it advances goes unattended due to negligence on the part of the patient, as there are not disabling symptoms in very early cases and in most cases the patient sees a doctor in late stage with disability symptoms, which are now quite pronounced like burning sensation, trismus and difficulty in swallowing. ${ }^{4,5}$

Financial or Other, Competing Interest: None.

Submission 06-06-2016, Peer Review 20-06-2016,

Acceptance 22-06-2016, Published 24-06-2016.

Corresponding Author:

Dr. Sonu Shukla,

\#179-A, Harshwardhan Nagar,

Bhopal.

E-mail: sonushukla06@yahoo.com

DOI: $10.14260 /$ jemds/2016/751

\section{School Based Health Promotion}

Surveys have indicated that much of the tobacco chewers get this habit during school time. Hence, control programs should be forced at these sections of the society. School is an extraordinary setting in which to improve the health of the students, school personnel, families and members of the community should be involved. Therefore, reduction in the prevalence of gutkha chewing among school children is very important. 4,6

\section{AIMS AND OBJECTIVES}

1. To study the knowledge, attitude and practice regarding gutkha chewing in school children.

2. To study prevalence of gutkha chewing in school children in terms of frequency, type expenditure, cause, duration and age of starting.

3. To decrease gutkha chewing in school children.

4. To evaluate our methodology.

\section{METHODOLOGY}

All the students were informed and then teachers were consulted. A self-administered questionnaire was prepared to find out knowledge, attitude and practice of students through the questionnaire. Educational intervention was carried out by means of lecture using transparencies explaining the hazards of gutkha chewing. Then again post-intervention assessment was done through another questionnaire after a month's time. Selection of Subjects - Fifty school children of Class 11 and 12 were randomly selected. We considered $11^{\text {th }}$ and $12^{\text {th }}$ class students as having enough maturity to understand the subject of our study. 
Definition of Subject: Those students who chew gutkha. Definition of Control: Those students who do not chew gutkha.

\section{RESULTS AND OBSERVATION}

Knowledge and Attitude

\begin{tabular}{|c|c|c|c|}
\hline & \multicolumn{3}{|c|}{ Number of Students } \\
\hline & $\begin{array}{c}\text { Pre- } \\
\text { Intervention }\end{array}$ & $\begin{array}{c}\text { Post } \\
\text { Intervention }\end{array}$ & $\begin{array}{c}\text { \% } \\
\text { Improvement }\end{array}$ \\
\hline Yes & 34 & 48 & 28 \\
\hline No & 16 & 2 & 28 \\
\hline \multicolumn{3}{|c|}{$\begin{array}{c}\text { Table 1: Number of Students Aware of all Four } \\
\text { Ingredients of Gutkha being Tobacco, } \\
\text { Betel Nut, Lime and Areca }\end{array}$} \\
\hline
\end{tabular}

\begin{tabular}{|c|c|c|c|}
\hline & \multicolumn{3}{|c|}{ Number of Students } \\
\hline & $\begin{array}{c}\text { Pre- } \\
\text { Intervention }\end{array}$ & $\begin{array}{c}\text { Post } \\
\text { Intervention }\end{array}$ & $\begin{array}{c}\text { \% } \\
\text { Improvement }\end{array}$ \\
\hline Yes & 13 & 45 & 64 \\
\hline No & 37 & 5 & 64 \\
\hline \multicolumn{3}{|c|}{ Table 2: Number of Students Aware of the Fact that all } \\
Ingredients are Harmful
\end{tabular}

\begin{tabular}{|c|c|c|c|}
\hline & \multicolumn{3}{|c|}{ Number of Students } \\
\hline & $\begin{array}{c}\text { Pre- } \\
\text { Intervention }\end{array}$ & $\begin{array}{c}\text { Post } \\
\text { Intervention }\end{array}$ & $\begin{array}{c}\text { \% } \\
\text { Improvement }\end{array}$ \\
\hline Yes & 5 & 47 & 84 \\
\hline No & 45 & 3 & 84 \\
\hline \multicolumn{3}{|c|}{ Table 3: Knowledge of Cancerous Condition } \\
caused by Gutkha
\end{tabular}

\begin{tabular}{|c|c|c|c|}
\hline & \multicolumn{3}{|c|}{ Number of Students } \\
\hline & $\begin{array}{c}\text { Pre- } \\
\text { Intervention }\end{array}$ & $\begin{array}{c}\text { Post } \\
\text { Intervention }\end{array}$ & $\begin{array}{c}\% \\
\text { Improvement }\end{array}$ \\
\hline Yes & 4 & 47 & 86 \\
\hline No & 46 & 3 & 86 \\
\hline \multicolumn{2}{|c|}{$\begin{array}{c}\text { Table 4: Awareness about Gutkha Chewing being the } \\
\text { Most Common Cause of Oral Cancer in India }\end{array}$} \\
\hline
\end{tabular}

Personal Habits

\begin{tabular}{|c|c|c|c|}
\hline & \multicolumn{3}{|c|}{ Number of Students } \\
\hline & $\begin{array}{c}\text { Pre- } \\
\text { Intervention }\end{array}$ & $\begin{array}{c}\text { Post } \\
\text { Intervention }\end{array}$ & $\begin{array}{c}\text { \% } \\
\text { Improvement }\end{array}$ \\
\hline Yes & 32 & 25 & 21.7 \\
\hline No & 18 & 25 & 21.7 \\
\hline \multicolumn{3}{|c|}{ Table 5: Number of Students Indulging } \\
in Gutkha Chewing
\end{tabular}

\begin{tabular}{|c|c|c|c|}
\hline & \multicolumn{3}{|c|}{ Number of Students } \\
\hline & $\begin{array}{c}\text { Pre- } \\
\text { Intervention }\end{array}$ & $\begin{array}{c}\text { Post } \\
\text { Intervention }\end{array}$ & $\begin{array}{c}\text { \% } \\
\text { Improvement }\end{array}$ \\
\hline Male & 32 & 25 & 21.7 \\
\hline Female & 0 & 0 & 0 \\
\hline Total & $\mathbf{3 2}$ & 25 & $\mathbf{2 1 . 7}$ \\
\hline \multicolumn{4}{|c|}{$\begin{array}{c}\text { Table 6: Sex Wise Distribution of } \\
\text { Cause of Gutkha Chewing }\end{array}$} \\
\hline
\end{tabular}

\begin{tabular}{|c|c|c|c|}
\hline & \multicolumn{3}{|c|}{ Number of Students } \\
\hline & $\begin{array}{c}\text { Pre- } \\
\text { Intervention }\end{array}$ & $\begin{array}{c}\text { Post } \\
\text { Intervention }\end{array}$ & $\begin{array}{c}\% \\
\text { Improvement }\end{array}$ \\
\hline $\begin{array}{c}\text { With } \\
\text { Tobacco }\end{array}$ & 7 & 3 & 56.8 \\
\hline $\begin{array}{c}\text { Without } \\
\text { Tobacco }\end{array}$ & 25 & 22 & 12 \\
\hline Total & $\mathbf{3 2}$ & $\mathbf{2 5}$ & $\mathbf{2 1 . 7}$ \\
\hline \multicolumn{4}{|c|}{ Table 7: Type of Gutkha Consumed (With or Without } \\
Tobacco)
\end{tabular}

\begin{tabular}{|c|c|c|}
\hline No. of Pouches & Pre-Intervention & Post Intervention \\
\hline$<2$ & 5 & 15 \\
\hline $2-5$ & 20 & 8 \\
\hline$>5$ & 7 & 2 \\
\hline \multicolumn{2}{|c|}{ Table 8: Daily Consumption (In Pouches Per Day) } \\
\hline
\end{tabular}

\begin{tabular}{|c|c|c|}
\hline $\begin{array}{c}\text { Expense in } \\
\text { Rupees }\end{array}$ & $\begin{array}{c}\text { Pre- } \\
\text { Intervention }\end{array}$ & $\begin{array}{c}\text { Post } \\
\text { Intervention }\end{array}$ \\
\hline$<50$ & 8 & 20 \\
\hline $50-100$ & 16 & 4 \\
\hline 100 & 8 & 1 \\
\hline \multicolumn{2}{|c|}{ Table 9: Expenditure on Gutkha Per Month } \\
\hline
\end{tabular}

\begin{tabular}{|c|c|}
\hline Age in Years & Number of Students \\
\hline$<14$ & 6 \\
\hline $14-16$ & 22 \\
\hline$>16$ & 4 \\
\hline Table 10: Age When Started Gutkha Chewing \\
\hline
\end{tabular}

\begin{tabular}{|c|c|}
\hline Age in Years & Number of Students \\
\hline <6 Months & 10 \\
\hline 6 Months - 2 Years & 16 \\
\hline$>2$ Years & 6 \\
\hline Table 11: Duration of Consumption of Gutkha \\
\hline
\end{tabular}

\begin{tabular}{|c|c|c|}
\hline Causes & $\begin{array}{c}\text { Number of } \\
\text { Students }\end{array}$ & Percentage \\
\hline Peer Pressure & 25 & 50 \\
\hline Curiosity & 2 & 4 \\
\hline To Alleviate Boredom & 15 & 30 \\
\hline $\begin{array}{c}\text { Influence of } \\
\text { Advertisements }\end{array}$ & 1 & 2 \\
\hline Family Habit & 1 & 2 \\
\hline $\begin{array}{c}\text { Increase Work } \\
\text { Influence }\end{array}$ & 15 & 30 \\
\hline Easy Availability & 0 & 0 \\
\hline \multicolumn{2}{|c|}{ Table 12: Cause of Consumption of Gutkha } \\
\hline
\end{tabular}

\begin{tabular}{|c|c|c|}
\hline Causes & Number of Students & Percentage \\
\hline Exams & 25 & 50 \\
\hline Journey & 16 & 32 \\
\hline Stress & 8 & 16 \\
\hline \multicolumn{2}{|c|}{ Table 13: Consumption Increases During } \\
\hline
\end{tabular}

\begin{tabular}{|c|c|}
\hline \multicolumn{2}{|c|}{ Number of Students } \\
\hline Yes & No \\
\hline 20 & 5 \\
\hline Table 14: Number of Students who Tries to Quit after \\
Intervention (Specify Yes or No)
\end{tabular}

\begin{tabular}{|c|c|}
\hline Days & Number of Students \\
\hline$<10$ & 15 \\
\hline $10-20$ & 3 \\
\hline $20-30$ & 2 \\
\hline \multicolumn{2}{|c|}{$\begin{array}{l}\text { Table 15: For those who Tried } \\
\text { to Quit, 'Period of Abstinence' }\end{array}$} \\
\hline
\end{tabular}

\section{DISCUSSION}

Evidences show that the frequency of tobacco and betel nut chewing has increased, especially in west Pacific region. IARC has classified only betel nut as group 1 carcinogen and its use with tobacco further increases risk of oral carcinoma. The use of betel nut with tobacco is increasing because of aggressive marketing of tobacco products. Studies and surveys show that tobacco consumption has increased considerably amongst the 
youth and is responsible for deterioration of their health status. ${ }^{1,2}$

The above study led to a substantial improvement of $21.7 \%$ amongst the students of standard $11^{\text {th }}$ and $12^{\text {th }}$ class of St. Mary's Convent School, Indore. There was no prevalence of gutkha chewing seen among the females. The study caused a reduction in the number of pouches consumed by the students per day, who had not yet left the habit. The most vulnerable age of starting gutkha chewing was found to be 14-16 years. The main causes of gutkha consumption was peer pressure, boredom and to increase work efficiency. Increased consumption was seen during exams and majority of the students tried to quit, but could not stick to it.

J Muttapappallymyalil, J Sreedharan had done a study on smokeless tobacco consumption among school children and the results showed that the mean age of tobacco consumption was 14.4, while in the present study it was 15 . Similarly, in the study done by Krishna Dere and Prashant Chaudhary majority of the students who consumed tobacco were between 13-14 yrs. and approximately $38 \%$ of female students used tobacco, whereas in this study majority of the students involved in tobacco consumption were between 14-16 years; no female student was involved.1,2

Since most of the habits develop during adolescence, all interventions should be targeted at this level. Strict legislation in the college and school premises should be taken to ban the use of any tobacco products. The school authorities should promote shows that motivate students to abstain themselves from tobacco products and programmes should be held on special days like anti-tobacco day, so that student can be motivated. ${ }^{3}$

\section{CONCLUSION}

A reduction in the prevalence of gutkha chewing in the community could be brought about by an educational approach, which at the same time was helpful in improving the knowledge and attitude regarding gutkha chewing.

Our project succeeded in bringing about a reduction of $21.7 \%$ in gutkha chewing among school students of Class 11 and 12 of the St. Mary's Higher Secondary School, Indore.

\section{REFERENCES}

1. Muttapppallymyalil J, Shreedharan J, Divakaran B. Smokeless tobacco consumption among school children. Indian J Cancer 2010;47(Suppl 1):19-23.

2. Krishna D, Prashant C, Vijay B, et al. Prevalence and characteristics of chewing habits of areca nut and tobacco among school children of rural areas in and around Gandhi Nagar district, Gujarat. JoAOR 2014;5(2):20-26.

3. http//www.cdc.gov.in

4. http//medscape.com

5. http//currentmed.com

6. Park K. Parks textbook of preventive and social medicine. 19th edn. India: M/S Banarsidas Bharat Publishers 2007:311-16. 